Review Article

\title{
REVIEW ARTICLE ON LEUCAENA LEUCOCEPHALA AS ONE OF THE MIRACLE TIMBER TREES
}

\author{
MOHAMED Z. ZAYED ${ }^{1 *}$, SOBHY M. A. SALLAM ${ }^{2}$, NADER D. SHETTA ${ }^{1,3}$
}

${ }^{1}$ Forestry and Wood Technology Department, Faculty of Agriculture (EL-Shatby), Alexandria University, Alexandria, Egypt, ${ }^{2}$ Animal and Fish Production Department, Faculty of Agriculture, Alexandria University, Alexandria, El-Shatby, Egypt, ${ }^{3}$ Plant Production Department, Food and Agricultural Sciences College, King Saud University, Riyadh, Saudi Arabia

Email: zaky_tree@yahoo.com

Received: 03 Mar 2017 Revised and Accepted: 22 Nov 2017

\section{ABSTRACT}

Leucaena leucocephala trees are commonly known as White Lead tree. It is native to Southern Mexico and Northern Central America and spread across many tropical and sub-tropical locations. It has multipurpose uses, such as generation of firewood, timber, greens, fodder, and green manure, as well as to provide shade and control soil erosion. It has been used for medicinal purposes because of possessing multiple pharmacological properties. Studies have shown the presence of various secondary metabolites such as alkaloid, cardiac glycosides, tannins, flavonoids, saponins, and glycosides in this species. In traditional medicine, it is used to control stomach ache and as contraception and abortifacient. In the present study, the global distribution, taxonomy, chemical composition, pharmacological activities, and potential uses of Leucaena leucocephalaare discussed.

Keywords: Leucaena leucocephala, Medicinally, Multipurpose, Pharmacological activities, Traditional medicine

(C) 2018 The Authors. Published by Innovare Academic Sciences Pvt Ltd. This is an open access article under the CC BY license (http://creativecommons.org/licenses/by/4.0/) DOI: http://dx.doi.org/10.22159/ijpps.2018v10i1.18250

\section{INTRODUCTION}

Leucaena leucocephala (Family: Fabaceae) is a small, fastgrowing tree, and has multiple common names by which it is known such as White Lead tree, White Popinac, Jumbay, and Wild Tamarind [1]. It is native to Southern Mexico and Northern Central America and diffused in over 35 countries across all continents, except Antarctica (table 1) [2].

Table 1: The global distribution of Leucaena leucocephala [2]

\begin{tabular}{ll}
\hline Region & Countries \\
\hline Africa & Angola, Burundi, Cape Verde Is, Cameroon, Chad, Djibouti, Egypt, Equatorial Guinea, Ethiopia, Ghana, Guinea, Guinea Bissau, \\
& $\begin{array}{l}\text { Ivory Coast, Kenya, Liberia, Malawi, Mali, Mozambique, Niger, Nigeria, Sao Tome and Principe, Senegal, Sierra Leone, Somalia, } \\
\text { South Africa, Sudan, Tanzania, Togo, Uganda, Zaire and Zimbabwe }\end{array}$ \\
Asia & $\begin{array}{l}\text { Bhutan, Cambodia, India, Indonesia, Iraq, Iran, Laos, Malaysia, Pakistan, Philippines, Sri Lanka, Taiwan, Thailand, Vietnam and } \\
\text { Japan }\end{array}$ \\
Australasia & Australia, Papua New Guinea (New Guinea, New Britain and Bismarck Archipelago) \\
Caribbean & Bahamas, Bermuda, CaymanIs, Cuba, Dominican Republic, Grenada, Haiti, Jamaica, Puerto Rico \\
Central America & Costa Rica, El Salvador, Guatemala, Honduras, Mexico, Nicaragua, and Panama. \\
Europe & Spain \\
Indian Ocean & Aldabra, Chagos, Archipelago, Madagascar, Mauritius, Reunion Is. (Rodrigues Is., Seychelles, and Christmas Island. \\
Middle East & Saudi Arabia and Yemen. \\
North America & United States in Arizona, Georgia, Virgin Islands, Texas, Florida and Hawaii \\
Pacific Ocean & Caroline outer islands (Fiji), Polynesia (Tahiti, Moorea) \\
South America & Argentina, Bolivia, Brazil, Chile, Colombia, Guyana, Peru, Venezuela \\
\hline
\end{tabular}

Leucaena originated from the Greek words "leuc," which means "white," and "caen,"which means "new," referring to the whitish flowers. The species name also refers to the flowers: leucocephala from "leu," meaning white, and "cephala," meaning "head." L. leucocephala was known as a miracle tree because of its worldwide success as a long-lived and highly nutritious forage tree used to produce firewood, timber, human food, green manure, shade and also to control erosion. It is estimated to cover 2-5 million ha worldwide [3-5].

Medicinally it has been used for its antimicrobial, anthelmintic, antibacterial, anti-proliferative and antidiabetic, anticancer, cancer preventive, diuretic, anti-inflammatory, antioxidant; antitumor, antihistaminic, nematicide, pesticide, anti-androgenic, hypocholesterolemic, and hepatoprotective properties [6]. It spreads as a shrub or small tree growing up to $10 \mathrm{~m}$ in height throughout the cleared areas and forms dense thickets [7]. Leucaena species is an evergreen, drought-tolerant shrub or small tree, which flowers abundantly. Some species of Leucaena can grow up to $20 \mathrm{~m}$ in height and those are known as the Salvadorian type. Those species are considered as weeds in many parts of the world [8]. Leucaena leaves appear similar to those of tamarind, having white flowers tinged with yellow, and having long flattened pods. Seeds are dark brown with the hard shining seed coat. It has hard heavy wood (about $800 \mathrm{~kg} / \mathrm{m}$ ), with a pale yellow sapwood and light reddish-brown heartwood. Bark on young branches is smooth and grey-brown or salmon pink, whereas older barks are darker grey-brown, and rough with shallow, rusty orange-brown vertical fissures, and deep red inner bark [9].

Taxonomical classification

\begin{tabular}{ll} 
Kingdom & Plantae \\
Subkingdom & Tracheobionta \\
Superdivision & Spermatophyta \\
Division & Magnoliophyta \\
Class & Magnoliopsida \\
Subclass & Rosidae \\
Order & Fabales \\
Family & Fabaceae-Pea family \\
Genus & Leucaena Benth.-lead tree \\
Species & Leucaena leucocephala \\
\hline
\end{tabular}




\section{Other names}

Arabic: Leuceana

English: Leucaena, Jumpy-bean, Wild tamarind, Lead tree, White popinac, White

Lead tree, Horse tamarind.

French: Faux mimosa, Leucene, Delin étranger

Hindi: kadam, Toira, Subabul, Tagari, Koo babul, Lamtoro, Ku-babul

Indonesian: Klandingan, Lamtoro, Petai cina, Pelending

Japanese: Kladingan, Lamtoro.

Malay: Ipil-ipil, Petai jawa, Petai belalang

Spanish: Guaje, Salvador leucaena, Peru leucaena, Giant leucaena, Acacia bella rosa

Amharic: Lukina

Filipino: Elana, Kariskis, Palo-maria, Ipil ipil

Chinese: Yin he huan

\section{Botanical description}

The leaves of $L$. leucocephala are compound pinnate; pinnular rachis 5-10.2 cm long in general, are bipinnate with 6-8 pairs of pinnae bearing 9-20 pairs leaflets, linear-lanceolate 8-15 $\mathrm{mm}$ long, 2-4.5 $\mathrm{mm}$ wide, slightly asymmetric, acute at tip, linear-oblong to weakly elliptic, glabrous except on margins rounded to obtuse at base. $L$. leucocephala leaves fold up due to heat, cold or lack of water [10]. The paired inflorescences of axillary globose head measures between 12 and $20 \mathrm{~mm}$ in diameter, with the peduncle length measuring between 2 and $3 \mathrm{~cm}$, and numerous flowers produced. The axillaries are on long stalks, white in color, in dense global heads measuring 1-2 cm across; fruit pod with raised border, flat, thin; becoming dark brown and hard when mature, 10-15 cm long, 1.6$2.5 \mathrm{~cm}$ wide, dehiscent at both sutures and each legume contains 1520 hard, shiny, brown seeds that are flat and tear-drop shaped. This species is a polyploid with $2 \mathrm{n}=104$ chromosomes [11-15].

Flowering phenology of L. leucocephala varies widely among varieties and with respect to their growing location. However, it can flower all year-round [16]. L. leucocephala starts flowering within 4 to $6 \mathrm{mo}$ of seed germination. Usually, the flowering period is seasonal or twice a year. The spherical whitish flower heads are 2to $2.5 \mathrm{~cm}$ in diameter, 100 to 180 flowers for each head, 2 to 6 in leaf axils per group, arising on actively growing young shoots. The color of flowers can be white or pale cream-white and are borne on stalks 2 to $3 \mathrm{~cm}$ long at the ends or sides of twigs $[8,16]$.

Pods measure from $11 \mathrm{~cm}$ to $19 \mathrm{~cm}$ long, $15 \mathrm{~mm}$ to $21 \mathrm{~mm}$ wide, 5 to 20 for each flower head, linear-oblong shape, rounded at apex, flat, 8 to 18 seeded, mid-to orange-brown, glabrous and slightly lustrous in white velvety hairs, papery, opening along both margins. The seeds are hard, dark brown with a hard shining testa measured from $6.7 \mathrm{~mm}$ to $9.6 \mathrm{~mm}$ long, $4 \mathrm{~mm}$ to $6.3 \mathrm{~mm}$ wide, aligned transversely in pod.

From the first year onward, the fruits grow in abundance. The seeds are small (8 mm long), shiny, teardrop-shaped, flat and dark brown with a thin but fairly durable seed coat. There are about 17,000 to 21,000 seeds per kilogram $[17,18]$. The dispersal agents of the seeds in pastures are legumes, wind, ruminants, and non-ruminants. Legumes can release the seeds while they are still on the tree. The wind can carry the seeds to some distances. Ruminants and non-ruminants can eat the legumes and then disperse the seeds through their fecal matters [17, 18].

\section{Harvested fruits and germination requirements}

Leucaena leucocephala fruits are harvested from branches when it changes their color to dark brown before dehiscence. The fruits are sun-dried after harvest and then threshed to release seeds by beating the dried legumes in cloth bags [16]. L. leucocephala seeds can then be stored as un-scarified or scarified seeds. Unscarified seeds can be stored for more than one year under dry conditions at ambient temperature and up to $5 \mathrm{y}$ when stored at $2{ }^{\circ} \mathrm{C}$ to $6{ }^{\circ} \mathrm{C}$, dried. In contrast, scarified seeds can be stored for 6 mo to a year $[16,19,20]$.

The harvested seeds of L. leucocephala should be decontaminated from larvae using fumigation by exposing the seeds to $32 \mathrm{~g} / \mathrm{m}$ methyl bromide for $2 \mathrm{~h}$ at $27^{\circ} \mathrm{C}$. Although seeds can be sown directly after harvest without pre-sowing treatment, the seed germination, in that scenario becomes very low. Therefore, to increase the rate of germination, one of the pre-sowing treatments such as scarification, hot water treatment and/or sulfuric acid treatment should be used. Soaking L. leucocephala seeds in $100{ }^{\circ} \mathrm{C}$ water for $20 \mathrm{~s}$ and subsequently in water at room temperature for $48 \mathrm{~h}$ had the highest seed germination rate, higher cumulative germination (CGP) and shortened period of complete dormancy (CDP), when compared to the germination rate when seeds were soaked for only $24 \mathrm{~h}$ or untreated seeds [21].

Soaking L. leucocephala seeds in hot water at $80{ }^{\circ} \mathrm{C}$ for $3-4 \mathrm{~min}$ followed by soaking in the water at room temperature for $12 \mathrm{~h}$ or soaking L. leucocephala seeds in concentrated sulfuric acid for 15-30 min are the best pre-sowing treatments that can be used to increase the seed germination of L. leucocephala. However, scarification is the most effective treatment that can be used as pre-sowing inoculation of seeds as it facilitates good field establishment of nitrogen-fixing rhizobium bacteria in soil devoid of rhizobia strains [20].

Germination percentage of $L$. leucocephala seeds are $50 \%$ to $98 \%$ for fresh seeds $[8,19]$. The complete dormancy period for scarified seeds are 6 to $10 \mathrm{~d}$ after sowing and for unscarified seeds are 6 to 60 $\mathrm{d}$ after sowing [20]. The sowing of L. leucocephala seeds should be on or near the soil surface, but not any deeper than $2 \mathrm{~cm}$. For growth in the nursery, the growing medium should be well drained, have proper nutrients and water holding capacity, and have a $\mathrm{pH}$ between 5.5 and 7.5 [16]. Light shade is recommended during the seedling development and full sun thereafter [16]. In young seedlings, taproot development is rapid and seedlings reach plantable size of $20 \mathrm{~cm}$ height in 2 to 3 mo $[16,22]$. Weeding in plantations, until the seedlings outgrow competing grasses or herbaceous competitors in plant biomass, is recommended [16]. Direct seeding by planting container seedlings, bare root seedlings and stem cuttings of 2 to 5 $\mathrm{cm}$ in diameter can be used as a method of plantation development [23]. It grows moderately rapid but not as fast as the giant variety for which most of the data are available [24].

\section{Chemical composition and nutritive value}

The chemical composition analysis of the leaves of L. leucocephala from Malaysia revealed the presence of 30 compounds: tetratetracontane, oxalic acid, allyl hexadecyl ester, squalene, Octacosane, hexatriacontane, 5-octadecene, 1-octadecyne, 3,7,11,15tetramethyl-2-hexadecen-1-ol, pentadecanoic acid, 14-methyl-, methyl ester, 9,12-octadecadienoic acid, methyl ester, hexadecanoic acid, 15-methyl-, methyl ester, 9,12,15-octadecatrienoic acid, methyl ester and 3,7,11-tridecatrienenitrile, 4,8,12-trimethyl, 2-dodecene, 7-hexadecene,, 5-eicosene, 9,12,15-octadecatrienoic acid, methyl ester, 1-docosene, heptacosanoic acid, methyl ester, n-hexadecanoic acid, phytol and squalene [6]. The major chemical constituents of the leaves of L. leucocephala from Malaysia were Squalene (41.02\%), Phytol (33.80\%), 3, 7,11,15-Tetramethyl-2-hexadecen-1-ol (30.86\%) and 3,7,11-Tridecatrienenitrile, 4,8,12-trimethyl (25.64\%) [6], whereas the principal chemical constituents of the leaf extracts of the same species from Mexico were 2(H)-benzofuranone-5,6,7,7atetrahydro-4,4,7a-trimethyl, pentadecanoic acid-14-methyl-methyl ester, and 6,10,14-trimethyl-2-pentadecanone a ketone [25]. For whole plants of L. leucocephala from China the chemical composition were ficaprenol-11 (polyprenol), squalene, lupeol,-sitostenone, trans-coumaric acid, cis-coumaric acid, pheophytin-a, pheophorbide a methyl ester, methyl-132-hydroxy-(132-S)-pheophorbide-b and aristophyll-C [26].

The animal feeding pattern of Leucaena in Indonesia was studied by Lowry [27]. L. leucocephala is was known as a high potential fodder for several centuries. Its nutritional value is comparable or superior to alfalfa (Medicago sativa) with high ß-carotene content [24]. The leaves of L. leucocephala are most commonly used to feed chicken 
and pigs and processed as a pellet for freshwater fish. The dry matter digestibility (DMD) of L. leucocephala was $57.7 \%$ and crude protein based on the dry matter was $29.5 \%$ [28].

Forage quality of L. leucocephala is higher than other Leucaena species such as L. pallida and L. diversifolia as stated by Castillo et al. [29]. Leaves of L. leucocephala contained $6.70 \%$ moisture, $22.76 \%$ crude protein, $22.29 \%$ crude fibre, $4.60 \%$ fat, and $9.73 \%$ ash content [30]. In another study by El-Baha [31], leaves were reported to contain the highest percentage of minerals $(12.5 \%$ and $14.0 \%)$, pods the highest percentage of crude protein $(33.0 \%$ and $30.9 \%)$, twigs contained the highest percentage of crude fiber (31.5\% and 37\%) and calcium $(1.9 \%$ and $2.1 \%)$, and dry seeds possessed the highest percentage of crude fat $(7.2 \%$ and $10.1 \%)$ and nitrogen free extract (55.9\% and 58.8\%) for the 2-and 4-years-old plants, respectively.

\section{Use of Leucaena leucocephala as ruminant feeds}

Forage containing $40 \%$ to $60 \%$ L. leucocephala leaves gave a maximum gain in weight in rabbits, goats, sheep, and cows. Rushkin [32] reported that "L. leucocephala is palatable forage, digestible and serves to increase milk output in both the humid and the monsoonal tropics for ruminants and non-ruminants. However, when $L$. leucocephala is fed at levels above $7.5 \%$ (dry mass) of the diet, nonruminants lost weight and had general health problems due to the mimosine toxicity." When using L. leucocephala leaves in a rationed manner for fattening cattle, it is equivalent to cottonseed cake [33] and superior to groundnut cake [34]. In Queensland, Australia, a very high live weight gain was recorded using $L$. leucocephala leaves [32, 34-35] and the same is done as well in several other places [36].

Several reports showed that $L$. leucocephala could be a substitute for the imported protein supplements fed to dairy cows [32]. Dairy cattle produce well when fed with $L$. leucocephala [32, 37]. Henke and Morita [38] reported that dairy cows produce milk with higher fat content when they are fed with L. leucocephala compared to similar cows fed on pasture and concentrates or ammoniated rice straw in the grass-based diet. In Australia, Hawaii and Indonesia, annual milk production of 5,000 to $9,700 \mathrm{~L} / \mathrm{ha}$ was recorded [32]. Feeding cows and buffaloes on L. leucocephala foliage at $10 \%$ of their diets produce higher milk yield by $20 \%$ than that of the control group [39]. Jones [40] reported that feeding dairy cows on $L$. leucocephala foliage increases milk fat and protein contents and also increases milk production by $14 \%$ on average. Feeding dairy cows on grazing Brachiaria decumbens with L. leucocephala produce higher milk yield than cows fed only with grass. However, the use of L. leucocephala for cattle feedings has problems, due to mimosine toxicity. Symptoms of mimosine toxicity include infertility, decreased weight gain, goiter, cataract in young animals, and loss of hair [41]. Cattle fed completely on L. leucocephala will not die but may lose some of their coarse hairs. However, newborn calves have shown signs of enlarged thyroids, which may result in death within a few days if their mothers have signs of toxicity [42]. In addition, thyroxine levels were accounted to be higher in the group (10-month age) fed on an exclusive diet of L. leucocephala for 23 mo [43].

In sheep, L. leucocephala provides very palatable forage. Higher performances in sheep were noted when it is fed on dried $L$. leucocephala leaves at levels between $25 \%$ and $50 \%$ of grass hay [ 44 , 45]. In diet scarcity periods, sheep can be fed on higher amounts of dried L. leucocephala leaves [45-46]. The leaf meal or fresh leaves are comparable to rice straw in the grass-based diet of sheep because it increases DM intake, protein intake, $\mathrm{N}$ retention and thus improves growth performance of sheep and therefore is suitable to replace concentrated or ammoniated rice straw in the grass-based diet of sheep $[47,48]$. Feeding ruminant animals on L. leucocephala foliage increased survival rate and growth rate, for instance in lambs [49-51], rams [52, 53], and ewes [54].

In goats, L. leucocephala provides very palatable, digestible, and nutritious forage. L. leucocephala gives better dry matter intake, weight gain, and reproductive performance than other legumes such as alfalfa, Lablab purpureus, and Gliricidia sepium [54-57]. In a grassbased diet for goat, L. leucocephala dry matter foliage can be included at $30 \%$ to $75 \%$ [58-60], and it does not affect the goats' growth and milk production [60]. Fresh or wilted L. leucocephala is better than dried L. leucocephala leaves as a dry matter intake, growth rate and nitrogen utilization [61]. Angora goats fed on natural pastures with $45 \%$ of L. leucocephala leaf meal showed higher crude protein intake, weight gain and fibre growth $[62,63]$.

\section{Leucaena leucocephala as non-ruminant feeds}

Ruminant animals are able to tolerate mimosine than non-ruminants and therefore, L. leucocephala could not be a major portion of the non-ruminant diet. They could tolerate rations that contain up to $5 \%$ to $10 \%$ L. leucocephala (dry weight) [32]. The best rations used to growing pigs were $5 \%$ to $10 \%$ of $L$. leucocephala leaf meals $[64,65]$. To improve nitrogen retention, $L$. leucocephala was treated with acetic acid $(30 \mathrm{~g} / \mathrm{kg})$ or zeolite $(5 \%)$ and up to $20 \%$ L. leucocephala leaves or leaf meal can then be used to feed pigs $[66,67]$. Using up to $40 \%$ of $L$. leucocephala leaves in camel rations reduced feed conversion efficiency [67].

In poultry, $5 \%, 20 \%$ and $30 \%$ of $L$. leucocephala leaf meal in the diet caused a decline of feed intake, weight gain and egg production [6870]. These low performances may be due to the toxicity of mimosine or poor amino acid digestibility [71]. 5\% of L. leucocephala leaf meal in rations of broilers gave higher feed conversion [72]. 15\% of roasted L. leucocephala leaves can be included in rations with no effect on the decline of animal performance [73]. In laying hens, 6\% of $L$. leucocephala leaf meal in rations is recommended [74]. $L$. leucocephala can be used to reduce feed costs, improve animal performance and yolk colour by the xanthophyll which is extracted from L. leucocephala leaves [75].

Feeding rabbits on fresh or dried L. leucocephala or leaf meal improve animal performance. The inclusion of $24 \%$ to $40 \%$ of fresh L. leucocephala leaves is recommended for growing or fattening rabbits [76-81]. L. leucocephala can replace concentrate alfalfa (Medicago sativa) in the diet of rabbits [82]. L. leucocephala is more palatable than Arachis pintoi. $25 \%$ of $L$. leucocephala leaf meal can be included in supplementing a diet with cassava peels and Gliricidia sepium and $30 \%$ to $40 \%$ with Arachis pintoi. [83]. However, when more than $10 \%$ to $15 \%$ dried L. leucocephala was included in the diet and replaced with wheat bran resulted in a decrease in growth in rabbits. [84]. $20 \%$ to $25 \%$ of fresh L. leucocephala leaves in diet resulted up to $55 \%$ mortality of female and young rabbits [85-86].

For fish, a few studies have been used with $L$. leucocephala leaf meal as a protein source in fish feeds and the data obtained are conflicting. Hossain et al. [87] revealed improved growth responses of Clarias gariepinus (African catfish) on diets containing 30\% L. leucocephala leaf meal. However, Santiago et al. [88] obtained slow growth rate of $C$. macrocephalus (Asian catfish) on diets in which $30 \%$ of the fish meal was replaced by L. leucocephala leaf meal.

\section{Leucaena leucocephala as human food}

Almost every part of the L. leucocephala species is consumed as human food since the era of the Mayans [6]. In Indonesia, Thailand, and Central America, people eat the young leaves, flowers, and young pods in soups [6]. In the Philippine Islands, the young pods are cooked as a vegetable and roasted seeds are used as a substitute for coffee. The young dry seeds are popped like popcorn [6]. In Indonesia, Thailand, Mexico and Central America people also eat the young leaves, flowers, and young pods as an ingredient for soups and salads. Seeds are being considered as non-conventional sources of protein, together with other leguminous seeds [6]. In addition, it is one of the medicinal plants used to control stomach ache, as contraception and abortifacient.

\section{Phytochemical studies}

The phytochemical screening of leaf extract of L. leucocephala revealed the presence of various secondary metabolites as alkaloid, cardiac glycosides, tannins, flavonoids, saponins and Glycosides [3].

Bioactivity studies on this plant revealed its anthelmintic, antibacterial, anti-proliferative and antidiabetic activities [8]. The L. leucocephala leaves possess many biological properties such as antimicrobial, anticancer, cancer preventive, diuretic, anti-inflammatory, antioxidant; antitumor, antihistaminic, nematicide, pesticide, antiandrogenic, hypocholesterolemic and hepatoprotective (table 2) [6]. 
Table 2: Phytochemical compounds identified from the L. leucocephala leaf extracts and their therapeutic Activity [6]

\begin{tabular}{|c|c|c|c|}
\hline No & Compound & $\begin{array}{l}\text { Secondary } \\
\text { metabolite }\end{array}$ & Therapeutic activity \\
\hline 1 & Phytol & Diterpene & Antimicrobial, anticancer, cancer preventive, diuretic, anti-inflammatory \\
\hline 2 & Squalene & Triterpene & $\begin{array}{l}\text { Antibacterial, antioxidant, antitumor; cancer-Preventive, chemopreventive; } \\
\text { immunostimulant, lipoxygenase-inhibitor, perfumery, pesticide, sunscreen }\end{array}$ \\
\hline 3 & n-Hexadecanoic acid & Palmitic acid & $\begin{array}{l}\text { Antioxidant, hypocholesterolemic nematicide, pesticide, antiandrogenic, flavor, } \\
\text { hemolytic, 5-alpha reductase inhibitor }\end{array}$ \\
\hline 4 & $\begin{array}{l}\text { Pentadecanoic acid, 14-methyl-, } \\
\text { methyl ester }\end{array}$ & $\begin{array}{l}\text { Palmitic acid } \\
\text { methyl ester }\end{array}$ & Antioxidant. \\
\hline 5 & $\begin{array}{l}\text { Hexadecanoic acid, 15-methyl-, } \\
\text { methyl ester }\end{array}$ & Fatty acid ester & Antioxidant, nematicide, pesticide, flavor, antiandrogenic \\
\hline 6 & $\begin{array}{l}\text { 3,7,11,15-Tetramethyl-2- } \\
\text { hexadecen-1-ol }\end{array}$ & Terpene alcohol & Antimicrobial \\
\hline 7 & $\begin{array}{l}9,12,15 \text {-Octadecatrienoic acid, } \\
\text { methyl ester }\end{array}$ & $\begin{array}{l}\text { Linolenic acid } \\
\text { ester }\end{array}$ & $\begin{array}{l}\text { Anti-inflammatory, insectifuge hypocholesterolemic, cancer preventive, } \\
\text { nematicide, hepatoprotective, insectifuge, antihistaminic, antieczemic, antiacne, 5- } \\
\text { alpha-reductase inhibitor, antiandrogenic, antiarthritic, anti-coronary }\end{array}$ \\
\hline 8 & $\begin{array}{l}\text { 9,12-Octadecadienoic acid, methyl } \\
\text { ester }\end{array}$ & $\begin{array}{l}\text { Linolenic acid } \\
\text { ester }\end{array}$ & $\begin{array}{l}\text { Anti-inflammatory, nematicide, insectifuge, hypocholesterolemic, cancer } \\
\text { preventive, hepatoprotective, antihistaminic, antiacne, antiarthritic, antieczemic }\end{array}$ \\
\hline 9 & Oxalic acid, allyl hexadecyl ester & $\begin{array}{l}\text { Dicarboxylic } \\
\text { acid }\end{array}$ & $\begin{array}{l}\text { Acaricide, antiseptic, CNS-paralytic, fatal, hemostatic, irritant, pesticide, renotoxic, } \\
\text { varroacide. }\end{array}$ \\
\hline
\end{tabular}

(Modified from Dr. Duke's: phytochemical and ethnobotanical databases)

L. leucocephala seeds have great medicinal properties and are used to control stomachache, as contraception and abortifacient. The seed gum used as a binder in tablet formulation [6]. A sulfated glycosylated form of polysaccharides from the seeds was reported to possess significant cancer chemo-preventive and antiproliferative activities [1]. The extracts of the seeds have reported as anthelmintic, antidiabetic and have a broad spectrum antibacterial activity [1]. Recently, the seed oil was used in engineering as a novel bio-device useful in biomembrane modelling in lipophilicity determination of drugs and xenobiotics [1]. The plant is reported to be a worm repellent.

\section{Pharmacological activities}

\section{Antioxidant activity}

L. leucocephala leaf and seed extracts have antioxidant activity [89]. Leaf extracts contain, as a principal constituent, 2-(H)benzofuranone-5, 6, 7, 7a-tetrahydro-4, 4, 7a-trimethyl [25] and phenolic compounds and flavonoid quercitin was also isolated from the leaves extracts [90].

L. leucocephala seed extracts have antioxidant activity. The antioxidant activity is likely due to the phenolic content. An application of this extract should be considered as it can affect renal function by reducing the levels of albumin, ALP and total protein [91].

\section{Antidiabetic activity}

L. leucocephala has been reported to possess medicinal properties that control stomach diseases, facilitate abortion and provide contraception, and it is often used as an alternative, complementary treatment for diabetes [25]. Leaf and seed extracts also have antidiabetic activity [90]. An aqueous extract derived from its boiled seeds was taken orally to treat Type-2 diabetes [92].

The seed extract from L. leucocephala inhibits elevated blood glucose and lipids levels but increases the number of pancreatic islets [93]. The active fractions from L. leucocephala seeds have been reported to have antidiabetic activity [94]. Moreover, the seed extract from $L$. leucocephala exhibits antidiabetic and antioxidant activities and can be used for the treatment of diabetes without affecting hepatic function, but there is an impact on renal function [91]. In Indonesia, an aqueous extract derived from boiling the seeds of L. leucocephala is taken orally to treat type-2 (NIDDM) diabetes and is claimed to be efficacious [95].

\section{Antimicrobial activity}

L. leucocephala seed oil extract had a concentration-dependent activity against both Gram-positive (Staphylococcus aureus, Bacillus subtilis) and Gram-negative (Pseudomonas aeruginosa, Esherichia coli) bacteria and the lotion formulation with an emulsifying agent had good pharmaceutical properties [96]. The crude extract of $L$. leucocephala leaves exhibits anti-tubercular activity that supports the use of this plant as mentioned in the folklores [97].

\section{Anti-inflammatory}

The anti-inflammatory property of chloroform, ethyl acetate and methanol extracts of leaves of $L$. leucocephala was reported [6].

\section{Antitumor activity}

Hexane, petroleum ether, ethyl acetate and methanol extracts of leaves of L. leucocephala showed antitumor activity [6].

\section{Wood uses of L. leucocephala}

Its uses have been expanded to gum production, furniture and construction timber, pole wood, and pulpwood $[3,24]$

\section{CONCLUSION}

L. leucocephala is one of the miracle timber trees. It has multipurpose uses including beneficial pharmacological properties. Further studies revealed the presence of various secondary metabolites as alkaloid, cardiac glycosides, tannins, flavonoids, saponins and Glycosides. Its seeds have great medicinal properties and used to control stomachache, as contraception and abortifacient. The seed gum used as a binder in tablet formulation and the extracts of the seeds used as anthelmintic, antidiabetic and has a broad spectrum antibacterial activity. To date, no information is available about the pharmacological activities of flower, fruit, bark, wood branch, stem and root of L. leucocephala which need further studies.

\section{CONFLICT OF INTERESTS}

Declared none

\section{AUTHORS CONTRIBUTIONS}

All the author have contributed equally

\section{REFERENCES}

1. V Meena Devi, VN Ariharan, P Nagendra Prasad. Nutritive value and potential uses of Leucaena Leucocephala as Biofuel-a mini review. Res J Pharm Biol Chem Sci 2013;4:515-21.

2. L Holm, JV Pacho, JP Herberger, DL Plucknett. A geographical atlas of world weeds. Malabar, Florida: Krieger Publishing Company; 1979.

3. J Brewbaker, CT Sorensson. New tree crops from interspecific Leucaena hybrids. In: Janick J, Simon JE. editors. Advances in new crops. Portland: Timber Press; 1990. p. 283-9. 
4. F Awe, AO Giwa-Ajeniya, AA Akinyemi, GNO Ezeri. Phytochemical analysis of Acalypha wilkesiana, Leucaena leucocephala, Pepperomia pellucida and Sena alata leaves. Indian J Environ Sci 2013;2:41-4.

5. J Brewbaker, DL Plucknett, V Gonzalez. Varietal variation and yield trials of Leucaena leucocephala (Koa Haole) in Hawaii. Hawaii Agric Exp St Res Bull 1972;166:1-29.

6. M Zayed, S Benedict. Phytochemical constituents of the leaves of Leucaena leucocephala from malaysia. Int J Pharm Pharm Sci 2016;8:174-9.

7. M Takahashi, JC Ripperton. Koa haole (Leucaena glauca), its establishment culture and utilization as a forage crop. Hawaii Agric Exp Stn Bull 1949;100:58.

8. NAS. Agroforestry in the West African Sahel. BOSTID, National Academy of Sciences: Washington, DC, USA; 1984.

9. C Orwa, A Mutua, $\mathrm{R}$ Kindt, $\mathrm{R}$ Jamnadass, $\mathrm{S}$ Anthony. Agroforestree database: a tree reference and selection guide version 4.0; 1984.

10. J Duke. Handbook of energy crops: Leucaena leucocephala (Lam.) de Wit. Center for New Crops and Plants Products, Purdue University, West Lafayette, IN; 1983. p. 5.

11. E Little, FH Wadsworth. Common trees of puerto rico and the virgin islands. Agriculture Handbook 249. U. S. Department of Agriculture, Forest Service: Washington, DC, USA; 1964.

12. T Pennington, J Sarukhan. Arboles tropicales de México. Instituto Nacional de Investigaciones Forestales, Secretaria de Agricultura y Ganadaria. Mexico D. F., Mexico; 1968. p. 413.

13. R Howard. Flora of the lesser antilles, leeward and windward islands. Dicotyledoneae. Part 1. Jamaica Plain. MA: Arnold Arboretum, Harvard University; 1988. p. 4, 673.

14. H Liogier. Descriptive flora of Puerto Rico and adjacent islands. Spermatophyta. Editorial de la Universidad de Puerto Rico, Rio Piedras, PR; 1988;2:1-481.

15. W Stevens, C Ulloa, A Pool, OM Montiel. Flora de nicaragua. monographs in systematic botany. Missouri Botanical Garden, St. Louis, MO; 2001;85:945-1910.

16. R Van den Beldt, JL Brewbaker. Leucaena: wood production and use. Hawaii, USA: Nitrogen Fixing Tree Association; 1985. p. 50.

17. M Dijkman. Leucaena a promising soil erosion control plant. Econ Bot 1950;4:337-49.

18. Catie. Silvicultura de especies promisorias para producción de leña en América Central. Resultados de 5 años de investigación. Serie Tecnica Informe Tecnico 1986;86:177-200.

19. B Duguma, BT Kang, DU Okali. Factors affecting germination of Leucaena leuocephala. Seed Sci Tech 1988;16:489-500.

20. J Parrotta. Leucaena leucocephala (Lam.) de Wit: Leucaena tantan. Res. Note SO-ITF-SM-52. New Orleans, LA. USDA Fores T Service. Southern Forest Experiment Estation; 1992. p. 8.

21. M Zayed, BA Fasihuddin, W Ho, S Pang. EMS-induced mutagenesis and DNA polymorphism assessment through ISSR markers in Neolamarckia cadamba (kelampayan)and Leucaena leucocephala (petai belalang). Eur J Exp Bio 2014;4:156-63.

22. S Westwood. The optimum growing period in the nursery for six important tree species in lowland Nepal. Banko Janakari 1987;1:5-12.

23. J Francis. Leucaena leucocephala established by direst seeding in prepared seed spots under difficult conditions. NFTRR 1993;11:91-3.

24. NAS (National Academy of Sciences). Leucaena: Promising forage and tree crop for the tropics. Washington D. C. USA; 1977.

25. A Salem, MZ Salem, M Gonzalez-Ronquillo, LM Camacho, M Cipriano. Major chemical constituents of Leucaena leucocephala and Salix babylonica leaf extracts. J Trop Agric 2011;49:95-8.

26. C Chen, Y Wang. Polyprenol from the whole plants of Leucaena leucocephala. J Environ Prot 2010;1:70-2.

27. J Lowry. The role of leucaena leucocephala in animal feeding in Indonesia. Seminar Nasional lamtoro I, (BPPT) Jakarta; 1982.

28. R Wheeler, WR Chaney, KD Johnson, LG Butler. Leucaena forage analysis using near infrared reflectance spectroscopy. Anim Feed SciTech 1996;64:1-9.

29. A Castillo, OC Cuyugen, S Foarty, HM Shelkon. Growth, psyllid resistance and forage quality of Leucaena leucocephala, $L$. pallida, L. diversifolia and the hybrid of $L$. leucocephala $L$. pallida. Trop Grassl 1997;31:188-200.

30. S Atawodi, D Mari, JC Atawodi, Y Yahaya. Assessment of Leucaena leucocephala leaves as a feed supplement in laying hens. Afr J Biotechnol 2008;7:317-21.

31. A El-Baha. Biomass yield, chemical analysis, specific gravity and a fiber length of Leucaena leucocephala trees planted in sandy soil, at different ages and spacings. Alexandria J Agric Res 2002;47:215-22.

32. F Ruskin. Ed. Leucaena promising forage and tree crops for the tropics. $2^{\text {nd }}$ ed. National Research Council. Washington DC. National Academy Press; 1984.

33. D Thomas, BL Addy. Stall-fed beef production in Malawi. World Rev Anim Prod 1977;13:23-30.

34. B Hulman, E Owen, T Preston. Comparison of Leucaena leucocephala and groundnut cake as protein sources for beef cattle fed ad libitum molasses/urea in Mauritius. Trop Anim Prod 1978;3:1-8.

35. U Ter Meulen, S Struck, E Schulke, EA El-Harith. A review on the nutritive value and toxic aspects of Leucaena leucocephala. Trop Anim Prod 1979;4:113-26.

36. B Sobale, ST Kharat, VL Prasad, AL Joshi, DV Rangnekar, SS Deshmukh. Nutritive value of Leucaena leucocephala for growing bull calves. Trop Anim Health Food Prod 1978;10:23741.

37. J Flores, TH Stobbs, DJ Minson. The influence of the legume Leucaenaleucocephala and formal-caseia on the production and composition of milk from grazing cows. J Agric Sci 1979;92:351-7.

38. L Henke, K Morita. Value of koa haole as a feed for dairy cows. Circular No. 44, University of Hawaii College of Agriculture, Honolulu, Hawaii; 1954.

39. S Ghatnekar, DG Auti, VS Kamat. Feeding leucaena to Mozambique tilapia and Indian major carp. In: IDRC $2^{\text {nd }}$ Intl Workshop on leucaena Research in the Asia Pacific Region, Singapore, IDRC 211, Unipub, New York; 1983. p. 61-3.

40. R Jones, GA Bunch. Long-term records of legume persistence and animal production from pastures based on Safari Kenya clover and leucaena in subtropical coastal Queensland. Tropical Grasslands 1995;29:74-80.

41. M Hegarty, PG Schinckel, RD Court. The reaction of sheep to the consumption of Leucaena glauca and to its toxic principle mimosine. Austr J Agric Res 1964;15:53-67.

42. N Kewalramani, KS Ramchandra, US Upadhyay, VK Gupta. Proximate composition, mimosine and mineral contents of Leucaenasp and hybrids. Indian J Anim Sci 1987;57:117-20.

43. J Holmes, JD Humphrey, EA Walton, JD O'Shea. Cataracts, goitre and infertility in cattle grazed on an exclusive diet of Leucaena leucocephala. Austr Vet J 1981;57:257-60.

44. N Tomkins, NP McMeniman, RC Daniel. Voluntary feed intake and digestibility by red deer (Cervus elaphus) and sheep (Ovis ovis) of pangola grass (Digitaria decumbens) with or without a supplement of leucaena (Leucaena leucocephala). Small Rumin Res 1991;5:337-45.

45. I Osakwe, H Steingass. Ruminal fermentation and nutrient digestion in West African Dwarf (WAD) sheep fed Leucaena leucocephala supplemental diets. Agroforestry Sys 2006;67:129-33.

46. A Souza, GB Espindola. Effect of supplementation with Leucaena leucocephala hay during the dry season on the ponderal development sheep. Rev Bras Zootec 1999;28:1424-9.

47. E Orden, SA Abdulrazak, EM Cruz, ME Orden, T Ichinohe, T Fujihara. Leucaena leucocephala and Gliricidia sepium supplementation in sheep fed with ammonia-treated rice straw: effects on intake, digestibility, microbial protein yield and live-weight changes. Asian-Austral J Anim Sci 2000;13:1659-66.

48. F Espinoza, Y Diaz, P Argenti, H Quintana, L Leon. Use of leucaena meal (Leucaena leucocephala) on the post-weaning lamb feeding during the dry season. Rev Facultad Agronomia Universidad Zulia 2005;22:42-53.

49. L Reynolds, So Adediran. The effects of browse supplementation on the productivity of West African Dwarf sheep over two reproductive cycles. Goat production in the 
humid tropics. Proceedings of a workshop at the University of Ife, Ile Ife Nigeria; 1987.

50. D Negussie, S Teshome, T Azage. Growth rates and testicular characteristics of Ethiopian highland sheep offered chickpea haulm supplemented with incremental levels of Leucaena leucocephala leaf hay. Livest Prod Sci 2000;65:209-17.

51. I Nsahlai, BK Byebwa, ML Bonsi, DO Umesiobi. Short-term effects of Leucaena leucocephala feeding on growth, reproductive characteristics and blood mineral profile of South Africa Merino rams. Indian J Anim Sci 2005;75:1329-31.

52. A Selaive-Villarroel, CC Cavalcanti-Neto, VJ Freitas. Effect of flushing with Leucaena (Leucaena leucocephala (Lam) of Wit) on ovulation rate in Crioulo hair tropical ewes. Rev Brasileira Reproducao Animal 2002;26:112-4.

53. E Pamo, F Tendonkeng, JR Kana, PK Loyem, E Tchapga, FK Fotie. Effect of different levels of supplementation with Leucaena leucocephala on weight gains of the West African Dwarf goat. Revue d'elevage Medecine Veterinaire Des Pays Tropicaux 2004;57:107-12.

54. An Akingbade, IV Nsahlai, CD Morris. Reproductive performance, colostrum and milk constituents of mimosine adapted South African Ngunigoats on Leucaena leucocephalagrass or natural pastures. Small Rumin Res 2004;52:253-60.

55. J Kanani, SD Lukefahr, RL Stanko. Evaluation of tropical forage legumes (Medicago sativa, Dolichos lablab, Leucaena leucocephala and Desmanthus bicornutus) for growing goats. Small Rumin Res 2006;65:1-7.

56. Babayemi, FT Ajayi, AA Taiwo, MA Bamikole, AK Fajimi. Performance of West African dwarf goats fed Panicum maximum and concentrate diets supplemented with Lablab (Lablab purpureus), Leucaena (Leucaena leucocephala) and Gliricidia (Gliricidia sepium) foliage. Nigerian J Anim Prod 2006;33:102-11.

57. S Odeyinka. Effect of feeding varying levels of Leucaena leucocephala and Gliricidia sepium on the performance of West African Dwarf goats. Nigerian J Anim Prod 2001;28:61-4.

58. T Dutta, PK Sahoo, S Nawab, SB Rao, UB Chaudhary. Partial replacement of concentrate mixture with Leucaena leucocephala leaves in the pelleted feed of goats. Indian J Anim Sci 2002;72:820-2.

59. E Aregheore, D Perera, MS Yahaya. Nutritive value of Batiki grass (Ischaemum aristatum var. indicum) supplemented with leaves of browses (Gliricidia sepium and Leucaena leucocephala) on the performance of goats. Int J Agric Biol 2004;6:143-8.

60. T Clavero, R Razz. The performance of goats browsing Leucaena leucocephala in the semi-arid areas of northwest Venezuela. Revista Cientifica Facultad Ciencias Veterinarias Universidad Del Zulia 2003;13:460-3.

61. E Aregheore. Voluntary intake and digestibility of fresh, wilted and dry Leucaena (Leucaena leucocephala) at four levels to a basal diet of guinea grass (Panicum maximum). Asian-Aust J Anim Sci 2002;15:1139-46.

62. A Yami, AJ Litherland, JJ Davis, T Sahlu, R Puchala, AL Goetsch. Effects of dietary level of Leucaena leucocephala on the performance of angora and spanish doelings. Small Ruminant Res 2000;38:17-27.

63. C Rubanza, MN Shem, SS Bakengesa, T Ichinohe, T Fujihara. Effects of Acacia nilotica, A. polyacantha and Leucaena leucocephala leaf meal supplementation on performance of Small East African goats fed native pasture hay basal forages. Small Rumin Res 2007;70:165-73.

64. $\mathrm{R}$ Isaac, $\mathrm{R}$ Oswaldo. Effects of leucaena (Leucaena leucocephala) leaf flour in the feeding of finishing pigs. Revista Cientifica Facultad Ciencias Veterinarias Universidad Del Zulia 1995;5:131-7.

65. J Ly, JL Reyes, M Macias, V Martinez, PL Dominguez, R Ruiz. Ileal and total tract digestibility of leucaena meal (Leucaena leucocephala Lam. de Wit) in growing pigs. Anim Feed Sci Technol 1998;70:265-73.

66. V Echeverria, R Belmar, J Ly, RH Santos-Ricalde. Effect of Leucaena leucocephala leaf meal treated with acetic acid or sodium hydroxide on apparent digestibility and nitrogen retention in pig diets. Anim Feed Sci Technol 2003;101:151-9.
67. A Rai, ND Khanna, SP Agarwal. Effect of feeding Leucaena leucocephala with Phaseolus aconitifolius on growth and thyroid status of camel calves. Indian J Anim Sci 1992;62:297301.

68. N Librojo, JN Hathcock. Metabolism of mimosine and other compounds from Leucaena leucocephala by the chicken. Nutr Rep Int 1974;9:217-22.

69. S Berry, PK D'Mello. A composition of Leucaena leucocephala and grass meals as sources of yolk pigments in diets of laying hens. Trop Anim Prod1981;6:167-73.

70. ML Scott, MC Nesheim, RJ Young. Nutrition of chicken. ML Scott and Associates publishers, Ithaca, NY; 1982.

71. M Picard, I Angulo, H Antoine, C Bouchot, B Sauveur. Some feeding strategies for poultry in hot and humid environments. Proceedings of the 10th annual conference of the Malaysian Society of Animal Production1987;110-16.

72. R Natanman, D Chandrasekaran. Subabul leaf meal (Leucaena leucocephala) as a protein supplement for broilers. Ind Vet J 1996;73:1042-4.

73. An Okonkwo, LJ Isaac, AJ Ebereso, BI Umoh, OO Usoro. Effect of roasted Leucaena leucocephala leaf meal on the performance of broiler chickens. Global J Pure Appl Sci2002;8:475-9.

74. M Sekhar, PS Readdy, PV Reddy, A Venkataramaiah, DS Rao. Utilization of subabul (Leucaena leucocephala) leaf meal in layer rations. Ind J Anim Nutr1998;153):194-7.

75. D Zongo, C Ba, O Diambra, M Coulibaly. Coloration effect of a natural source of pigment (Leucaena leucocephala) for use in poultry. Ann Zootech 1997;46:185-90.

76. J Muir, ES Massaete. Growth response in rabbits to various levels of Leucaena leucocephala fed fresh with a wheat bran diet. JZimbabwe SocAnim Prod1992;4:131-4.

77. C Onwuka, GO Adeliyi, WO Biobaku, IF Adu. Leucaena leucocephala leaves in rabbit diets. Leucaena Res Rep1992;13:65-7.

78. P Rohilla, KM Bujarbaruah. Effect of subabul (Leucaena leucocephala) feeding on growth and physiology of rabbits. J Hill Res1999;12:135-7.

79. P Rohilla, KM Bujarbaruah, M Kumar, G Singh. Haematological and biochemical responses of various levels of subabul (Leucaena leucocephala) leaves in growing rabbits. Ind J Anim Nutr2000;17:28-33.

80. D Nieves, B Silva, O Teran, C Gonzalez. Increasing levels of Leucaena leucocephala in fattening rabbits diets. Revista Cientifica, Facultad de Ciencias Veterinarias, Universidad del Zulia 2002;12:419-21.

81. D Adejumo. Performance and serum chemistry of rabbits fed graded levels of cassava peels, Leucaena leucocephala and Gliricidia sepium leaves based diets. Global J Pure Appl Sci2006;12:171-5.

82. C Scapinello, AC Furlan, CC Jobim, HG Faria, DF Figueiredo, AB Hernandes. Nutritive value and use of Leucaena hay (Leucaena leucocephala cv. Cunningham) for growing rabbits. Acta Scientiarum 2000;22:829-33.

83. D Nieves, B Silva, O Teran, C Gonzalez, J Ly. A note on the chemical composition and feeding characteristics of diets containing Leucaena leucocephala and Arachis pintoi for growing rabbits. Livest. Livest Res Rural Dev 2004;16:419-21.

84. R Parigi-Bini, M Cinetto, N Carotta. Digestibility and nutritive value of Leucaena leucocephala in growing rabbits. $3^{\text {rd }}$ World Rabbit Congress, Rome; 1984;1:399-407.

85. J Muir, ES Massaete. Growth response in rabbits to various levels of Leucaena leucocephala fed fresh with a wheat bran diet. J Zimbabwe Soc Anim Prod 1992;4:131-4.

86. M Sugur, KV Jamuna, TK Das, KN Mouly, KC Singh. Histological changes in muscles of broiler rabbits fed Leucaena leucocephala. Indian J Vet Anat 2001;13:83-4.

87. M Hossain, FH Shikha. Apparent protein digestibility coefficients of some low protein ingredients for African catfish, Clarias gariepinus. Bangladesh J Zool 1997;25:77-82.

88. C Santiago, AC Gonzal. Growth and reproductive performance of the Asian catfish Clarias macrocephalus (Gunther) fed artificial diets. J Appl Ichthyol 1997;13:37-40.

89. S Chowtivannakul, C Talubmook. Antioxidant and antidiabetic activities of leaf and seed extracts from Leucaena leucocephala 
(Lam.) de Wit. In: Proceeding of NATPRO 4. Chiang Mai, Thailand; 2012. p. 356-9.

90. Adekunle, A Aderogba. Nematicidal effects of Leucaena leucocephala and Gliricidia sepium extracts on Meloidogyne incognita infecting okra. J Agric Sci 2007;52:53-63.

91. P Chowtivannakul, S Buavaroon, T Chusri. Antidiabetic and antioxidant activities of seed extract from Leucaena leucocephala (Lam.) de Wit. Agric Natural Resources; 2017. p. 1-5.

92. N Joshi, M Mahajan. Infection and diabetes. In: Pickup JC, Williams G. Eds. Textbook of Diabetes, third ed. Blackwell Science, Malden MA, USA; 2003.

93. D Syamsudin, P Simanjuntak. The effects of Leucaena leucocephala (lmk) de Wit seeds on blood sugar levels: an experimental study. Int J Sci Res 2006;2:49-52.
94. R Syamsudin Sumarny, P Simanjuntak. Antidiabetic activity of active fractions of Leucaena leucocephala (lmk) de Wit seeds in an experimental model. Eur J Sci Res 2010;43:38491.

95. S Dalimarta. Ramuan tradisional untuk pengobatan diabetes melitus. Jakarta 2006. p. 3-15.

96. S Aderibigbe, OA Adetunji, MA Odeniyi. Antimicrobial and Pharmaceutical properties of the seed oil of Leucaena leucocephala (Lam.) de wit (Leguminosae). Afr J Biomed Res 2011;14:63-8.

97. S Arun Satyadev, M Viswanadha Murthy, $\mathrm{R}$ Saroja. Phytochemical screening and antitubercular efficacy of leaf extracts of Leucaena leucocephala. Indo-Am J Pharm Res 2015;5:1023-9. 